\title{
Ophthalmologica
}

Emmett T. Cunningham, J r., Rubens Belfort, J r.

\section{HIV/AIDS and the Eye}

A Global Perspective

Ophthalmology Monographs 15

American Academy of Ophthalmology, San Francisco, 2002

148 pp.; $\$ 68.00$

ISBN 1-56055-264-6

The human immunodeficiency virus (HIV) has infected more than 50 million people worldwide. Since the initial description of eye disorders in HIV-positive patients, nearly 20 years ago, a large number of papers have described the wide spectrum of ocular infections and tumors. The authors Cunningham and Belfort submitted a representative presentation of recent data on epidemiology, prevention of transmission and manifestations of HIV around the eye.

The epidemiology of HIV/AIDS is excellently presented and the mass of data are clearly defined in colored graphs and charts. In a short chapter the authors reflect on molecular mechanisms of the HIV genome and the recent antiviral therapy, but do not reflect on the ocular side effects of antiretroviral agents. Another short chapter gives some practical advice as regards handling eye fluids contaminated with HIV and guidelines for the desinfection of instruments. Opportunistic infections and tumors of the eye and adnexal orbital manifestations are discussed in five chapters with an emphasis on manifestations of AIDS/HIV in children. These clinical parts of the book are excellently illustrated with typical opportunistic infections of the eye, such as the different morphology of CMV retinitis or neuroophthalmic manifestations documented in contrast-enhanced magnet resonance imaging (MRI). In a short review the clinical courses of opportunistic infection are described and short therapeutic suggestions are given. The recent scientific advance in the therapy of CMV retinitis is very well summarized in a double-page chart, discussing all possibilities of intravenous or intraocular antiviral therapy. A single chapter focuses on the special conditions we find in the prevalence of opportunistic disorders in the developing world. There are differences in the expression of HIV-related disease in
Africa and Asia, e.g. there is more herpes zoster ophthalmicus in Africa than CMV retinitis, which is more dominant in North America and Asia. The autors close with an epilogue expressing the hope that in a global world the governments are starting to recognize the complexicity of HIV/AIDS in the developing world and help the poor to improve their bad conditions with antiretroviral therapy or effective vaccines in future.

This booklet can be recommended to all readers who are interested in the problems of the diagnostic and therapy of AIDS/HIVpositive patients with opportunistic infections of the eye.

Hermann O.C. Gümbel, Ulm

\section{D.-K. Böker, H.-D. Mennel, P. Hermanek, C.W. Spraul \\ Klassifikation maligner Tumoren des ZNS und der Augen}

Springer, Berlin 2002

268 pp.; EUR 29.95

ISBN 3-540-42620-5

Die standardisierte Therapie onkologischer Erkrankungen setzt eine relevante und exakte Klassifikation voraus. Im vorliegenden Buch wird nicht nur die TNM-Klassifikation der malignen Tumoren des Auges und seiner Adnexen dargestellt, sondern auch Typing und Grading. Flussdiagramme und Tabellen geben in komprimierter Form das diagnostische und therapeutische Vorgehen wieder. Augenärzten, Pathologen und Dokumentaren wird hier ein Nachschlagewerk zur Verfügung gestellt, mit dem eine international standardisierte exakte Tumorklassifikation erleichtert wird.

Holger Baatz, Frankfurt

\begin{tabular}{ll}
\hline KARGER & ( ) 2003 S. Karger AG, Basel \\
$\begin{array}{l}\text { Fax + 41 61306 1234 } \\
\text { E-Mail karger@karger.ch } \\
\text { www.karger.com }\end{array}$ & $\begin{array}{l}\text { Accessible online at: } \\
\text { www.karger.com/oph }\end{array}$
\end{tabular}

Fax +41613061234

www.karger.com 